\title{
Analysis of Physico-Chemical Properties and Available Macro Nutrient Status of Soil Blocks of Alwar District Rajasthan, India
}

\author{
Priyanka Yadav ${ }^{*}$, Narendra Swaroop and Tarence Thomas \\ Department of Soil Science and Agricultural Chemistry, Naini Agricultural Institute, \\ SHUATS, Prayagraj, UttarPradesh,India \\ *Corresponding author
}

\section{A B S T R A C T}

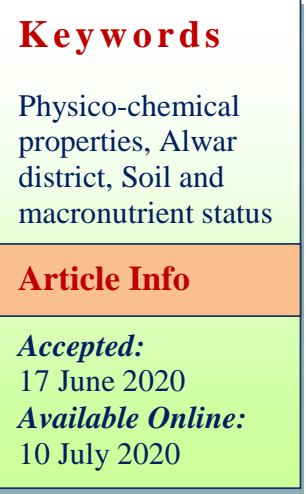

The present study was conducted to assess the physico-chemical properties and available N, P, K status of soil of Alwar district, Rajasthan using standard laboratory procedure. Soil samples were collected from three blocks (Mundawar, Behror, Neemarana) of the Alwar district from two depth viz. $0-15 \mathrm{~cm}$ and $15-30 \mathrm{~cm}$. Nine sampling points in different villages were selected for the analysis of $\mathrm{pH}$, electrical conducitivity (EC), Nitrogen, Phosphorus, Potassium, Soil texture i.e sand, silt and clay \% in soil, Water holding capacity, Percent pore space in soil. Results of the study indicated that $\mathrm{pH}$ ranges from 7.6 to 8.4. The EC ranges from 0.22 to $0.98 \mathrm{dSm}^{-1}$. The Nitrogen ranges from 87.5 to $184.1 \mathrm{Kg}$ $\mathrm{ha}^{-1}$.The Phosphorus ranges from 25 to $39 \mathrm{Kg} \mathrm{ha}^{-1}$.The Potassium ranges from 169 to 298 $\mathrm{Kg} \mathrm{ha}^{-1}$.The sand, silt and clay ranges were from $85.2-94.6 \%, 1.3-8.3 \%$ and $4.1-9.0 \%$ respectively. The soil texture varied from Fine sand to Loamy sand. Range of water holding capacity from $42.42 \%$ to $62.5 \%$ and percent pore space 37.86 to 58.9 including mean highest percent pore space $55.87 \%$ and the lowest percent space $42.35 \%$

\section{Introduction}

Soil consists of minerals and organic constituents, exhibits definite physical, chemical and biological properties of variable depth. Over the surface of earth provides a suitable medium for plant growth. The chemical properties of the soil are the interactions of various chemical constituents among soil particles and the soil solution. These physical and chemical properties are soil texture, bulk density particle density water holding capacity, soil structure, soil colour, $\mathrm{pH}$, electrical conductivity, cation exchange capacity, organic carbon, organic matter and soil nutrients (i.e divided as macro and micro nutrient). (Nautiyal and Kumar, 2004)Soil testing makes complete nutrient control a possibility, Fertilizer experiments are being patterned to determine economically optimum rates of nutrients application high yields with low production costs per unit are a must in modern farming.

Farmers of today are different in the failure is more certain and sooner unless they are obtaining reasonably high yields, improved drainage, many improved Cultural practices, 
better varieties, and control of insects and disease have helped to set the stage for high yields. As a result, the demand on the soil has gradually increased. Soil testing lets farmers know how much and what kind of fertilizer they must apply to be sure of returns from their investments in other improved practices (Joshi, et al., 2013).

The quality of soil is rather dynamic and can affect the sustainability and productivity of land use. It is the end product of soil degradative or conserving processes and is controlled by chemical, physical and biological components of a soil and their interactions (Papendick and Parr, 1992).

Limited studies are available so far on the changes in soil nutrient status over time in the drylands in general, and arid regions in particular where the sandy soils mostly suffer from several nutrient deficiencies. It has been documented (Wani 2008) that dryland soils are not only thirsty but also hungry.

In order to maintain and enhance the productivity of land, one needs to take-up not only proper soil and water management activities, but also appropriate knowledgebased soil nutrient management. In the arid sandy tract of western Rajasthan, the soils are usually deficient in several macro- and micronutrients, and there is large spatial variability in the plant-available nutrient content of the soils (Gupta et al., 2000; Praveen-Kumar et al., 2009; Mahesh Kumar et al., 2011a).

Also, the soils of the region do not receive adequate nutrient replenishment through flood, etc. as the region is devoid of any major perennial stream, and the rainfall is low. Consequently, productivity of the soils in arid region is also relatively low. The district Alwar of Rajasthan is considered as the driest part of country.

\section{Materials and Methods}

\section{Study area}

The district is located in the south-eastern part of Rajasthan. Geographically, the district lies at $25^{\circ} 43^{\prime} \mathrm{N}$ latitude and $75^{\circ} 65^{\prime} \mathrm{E}$ longitude and $268 \mathrm{~m}$ altitude. Geographical Area of Alwar district is $5,776 \mathrm{sq} \mathrm{km}$. It is approximately at a distance of $164 \mathrm{~km}$ from the state capital Jaipur.The climate of district is extremely hot in the summers and fairly cold in the winters. The prevailing climate in Alwar is known as local steppe climate. The climate here is classified as BSh by the Koppen-Geiger classification system. The average annual is $637 \mathrm{~mm}$.

\section{Sample collection and Analysis}

Soil samples were collected from three different blocks of Alwar district Rajasthan. They are Behror, Neemrana and Mundawar. Soil samples were collected with the help of Khurpi, spade and meter scale. In each block three village selected for sampling and samples obtained from two different depths 0$15 \mathrm{~cm}$ and $15-30 \mathrm{~cm}$, totally eighteen soil sample were collected then further were first air dried at room temperature, then crushed using wooden mallet and then sieved $(2 \mathrm{~mm})$ for further analysis.Water holding capacity (\%) was estimated by volume basis (Muthuvel 1992). The relative proportions of the various soil separates in a soil. Analysis of soil texture was done by Bouyoucos Hydrometer method (Bouyoucos, 1927).The pore space \%was calculated from the $100 \mathrm{ml}$ graduated measuring cylinder (Black, 1965). The soil was distilled with alkaline potassium permanganate as suggested by (Subbiah and Asija 1956) and the ammonia evolved was determined. $\mathrm{P}$ in the soil extract is determined colorimetrically using a Photoelectric Colorimeter after developing molybdenum blue colour (Olsen et al., 1954). The procedure was based on extraction with $1 \mathrm{~N} \mathrm{NH}_{4} \mathrm{OAC}$ 
(pH 7.0) and K was determined by Flame Photometer (Toth and Prince, 1949).The same procedure used for the estimation of $\mathrm{K}$.The $\mathrm{pH}$ was determined in 1:2 soil water suspensions using digital $\mathrm{pH}$ meter (Jackson, 1958). The EC was determined in 1:2 soil water suspensions using digital EC meter (Wilcox, 1950).

\section{Results and Discussion}

The Table. 1 and 2 depicted the soil texture in different blocks of Alwar district from depth (0-15 and 15-30). The Sand, Silt and Clay \% ranges from $85.2-94.6 \%, 1.3-8.3 \%$ and 4.1-9.0 \% respectively. The Table 1 and Figure 1.1shows the variation in water holding capacity at different depths $(0-15 \mathrm{~cm}$ and 15-30 cm) in Alwar district soils which are collected from few villages those are located nearby coastal areas. Water holding capacity of soil at $0-15 \mathrm{~cm}$ various between $42.85-62.5 \%$. Depth of $15-30 \mathrm{~cm}$ of soil showing $42.42-59.35 \%$ of water holding capacity. In this situation water holding capacity of soil high at $0-15 \mathrm{~cm}$ depth. The
Table1 and Figure 1.2 depicted the statistical accumulation on percent pore space of various farmers field and depths of $0-15$ and 15-30. \%Pore space varies between 37.86 56.15 at the depth of $0-15 \mathrm{~cm}$ of soil and 37.9 $-58.95 \%$ at the depth of $15-30 \mathrm{~cm}$ depth of the soil. It means increasing the depth results increasing $\%$ pore space of soils. The mean highest percent pore space $55.87 \%$ and the lowest percent space $42.35 \%$. The Table 1 and Figure 1.3 depicted the statistical accumulation on $\mathrm{pH}$ of various farmers field and depths. The $\mathrm{pH}$ ranges from7.6 -8.4 at 0$15 \mathrm{~cm}$ depth and $7.7-8.2$ at $15-30 \mathrm{~cm}$ depth. The highest mean value is recorded 8.25 and the least mean value 7.65 . When depth wise values were considered, $0-15 \mathrm{~cm}$ samples show lower $\mathrm{pH}$ when compared to $15-30 \mathrm{~cm}$ depth (deeper) soil samples. It means alkaline in nature these depth is having high amount of exchangeable sodium ions. it shows that higher amount of $\mathrm{pH}$ is present in $15-30 \mathrm{~cm}$ compared to $0-15 \mathrm{~cm}$ depth of soil. It occurs because of downward movement of water accumulation of cations in lower layers of soils.

Table.1 Physico-chemical parameter 9 sampling sites at depth (0-15) selected from three blocks of alwar district

\begin{tabular}{|l|l|l|l|l|l|l|l|l|l|}
\hline Parameters & $\mathbf{V 1}$ & $\mathbf{V 2}$ & $\mathbf{V 3}$ & $\mathbf{V 4}$ & $\mathbf{V 5}$ & $\mathbf{V 6}$ & $\mathbf{V 7}$ & $\mathbf{V 8}$ & $\mathbf{V 9}$ \\
& $\mathbf{0 - 1 5}$ & $\mathbf{0 - 1 5}$ & $\mathbf{0 - 1 5}$ & $\mathbf{0 - 1 5}$ & $\mathbf{0 - 1 5}$ & $\mathbf{0 - 1 5}$ & $\mathbf{0 - 1 5}$ & $\mathbf{0 - 1 5}$ & $\mathbf{0 - 1 5}$ \\
\hline $\mathbf{p H}$ & 8.2 & 8.0 & 7.9 & 8.3 & 7.8 & 7.8 & 8.4 & 7.6 & 7.8 \\
\hline EC & 0.27 & 0.22 & 0.37 & 0.89 & 0.94 & 0.89 & 0.91 & 0.78 & 0.96 \\
\hline \% Pore space & 46.8 & 45.2 & 37.86 & 51.66 & 56.15 & 46.8 & 53.1 & 50 & 46.8 \\
\hline $\begin{array}{l}\text { Water holding } \\
\text { capacity }\end{array}$ & 62.5 & 51.42 & 55.8 & 45.94 & 42.85 & 47.22 & 51.42 & 44.11 & 56.6 \\
\hline Sand\% & 86.0 & 88.5 & 89.5 & 94.6 & 94.0 & 94.0 & 85.2 & 85.2 & 86.2 \\
\hline Silt\% & 8.3 & 4.5 & 4.5 & 1.3 & 1.9 & 1.9 & 5.8 & 5.8 & 7.6 \\
\hline Clay\% & 5.7 & 7.0 & 6.0 & 4.1 & 4.2 & 4.2 & 9.0 & 9.0 & 6.2 \\
\hline Soil texture & Fine & Fine & Loamy & Fine & Fine & Fine & Loamy & Loamy & Loamy sand \\
& sand & sand & sand & sand & sand & sand & sand & sand & \\
\hline \multicolumn{1}{|c|}{ Avai N } & 151.2 & 98.3 & 117.2 & 91.2 & 162.7 & 103.4 & 109.3 & 127.2 & 117.2 \\
\hline Avai P & 39 & 36 & 36 & 31 & 27 & 26 & 30 & 33 & 36 \\
\hline K & 223 & 197 & 186 & 223 & 181 & 169 & 298 & 284 & 230 \\
\hline
\end{tabular}


Table.2 Physico-chemical parameter 9 sampling sites at depth (15-30) selected from three blocks of alwar district

\begin{tabular}{|l|l|l|l|l|l|l|l|l|l|}
\hline Parameters & $\mathbf{V 1}$ & $\mathbf{V 2}$ & $\mathbf{V 3}$ & $\mathbf{V 4}$ & $\mathbf{V 5}$ & $\mathbf{V 6}$ & $\mathbf{V 7}$ & $\mathbf{V 8}$ & $\mathbf{V 9}$ \\
& $\mathbf{1 5 - 3 0}$ & $\mathbf{1 5 - 3 0}$ & $\mathbf{1 5 - 3 0}$ & $\mathbf{1 5 - 3 0}$ & $\mathbf{1 5 - 3 0}$ & $\mathbf{1 5 - 3 0}$ & $\mathbf{1 5 - 3 0}$ & $\mathbf{1 5 - 3 0}$ & $\mathbf{1 5 - 3 0}$ \\
\hline $\mathbf{p H}$ & 7.9 & 7.9 & 8.0 & 8.2 & 7.7 & 7.8 & 8.0 & 7.7 & 7.7 \\
\hline EC & 0.30 & 0.32 & 0.45 & 0.94 & 0.96 & 0.98 & 0.79 & 0.70 & 0.94 \\
\hline \%Pore space & 53.1 & 44.5 & 56.9 & 53.4 & 55.6 & 37.9 & 41.2 & 58.95 & 45.18 \\
\hline $\begin{array}{l}\text { Water } \\
\text { holding } \\
\text { capacity }\end{array}$ & 57.57 & 57.14 & 59.35 & 47.2 & 42.4 & 43.2 & 48.48 & 48.57 & 58.06 \\
\hline Sand\% & & & & & & & & & \\
\hline Silt\% & 86.0 & 88.5 & 89.5 & 94.6 & 94.0 & 94.0 & 85.2 & 85.2 & 86.2 \\
\hline Clay\% & 8.3 & 4.5 & 4.5 & 1.3 & 1.9 & 1.9 & 5.8 & 5.8 & 7.6 \\
\hline Soil texture & Fine & Fine & Loamy & Fine & Fine & Fine & $\begin{array}{l}\text { Loamy } \\
\text { sand }\end{array}$ & $\begin{array}{l}\text { Loamy } \\
\text { sand }\end{array}$ & $\begin{array}{l}\text { Loamy } \\
\text { sand }\end{array}$ \\
\hline \multicolumn{1}{|c|}{ Avai N } & 138.7 & 102.1 & 87.5 & 99.4 & 170.2 & 134.2 & 129.4 & 139.2 & 184.1 \\
\hline Avai P & 38 & 33 & 38 & 33 & 25 & 27 & 32 & 34 & 38 \\
\hline K & 229 & 174 & 187 & 259 & 194 & 173 & 283 & 188 & 202 \\
\hline
\end{tabular}

Fig.1 Water holding capacity (\%) of farmer's field at 0-15 and 15-30 cm depths

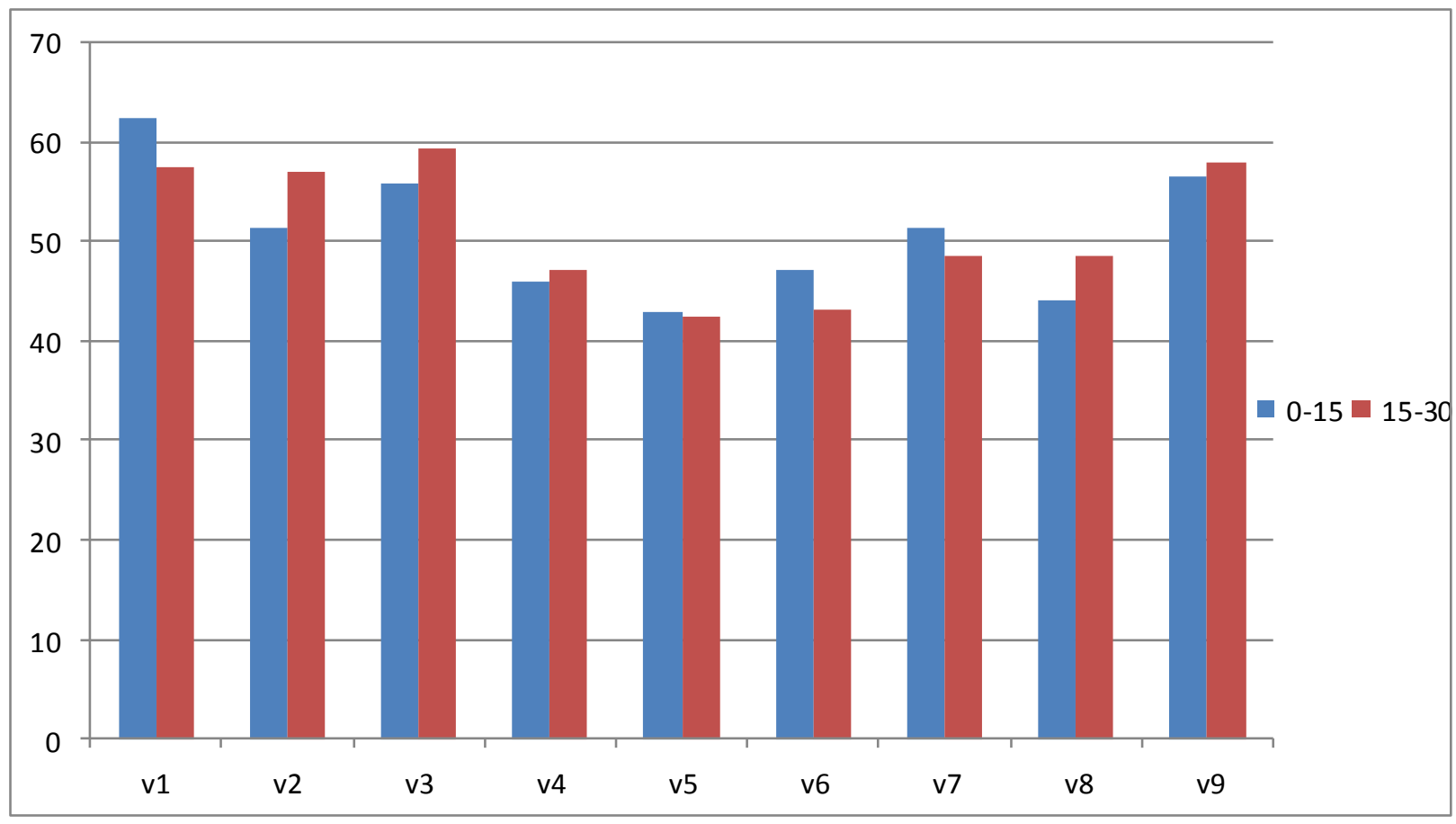


Fig.2 Percent Pore Space of farmer's field at 0-15 and 15-30 cm depths

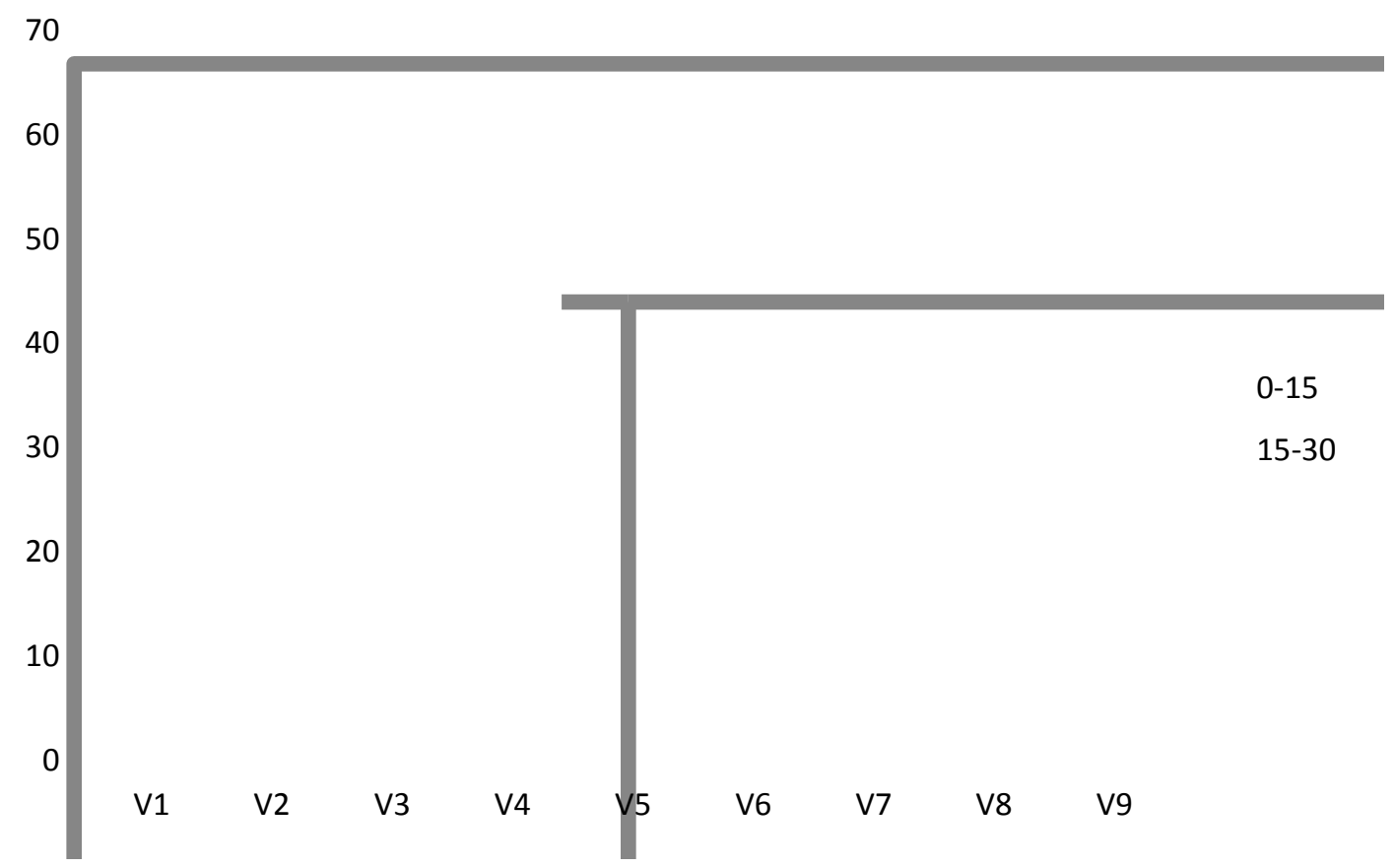

Fig.3 pH value of farmer's field at 0-15 and $15-30 \mathrm{~cm}$ depths

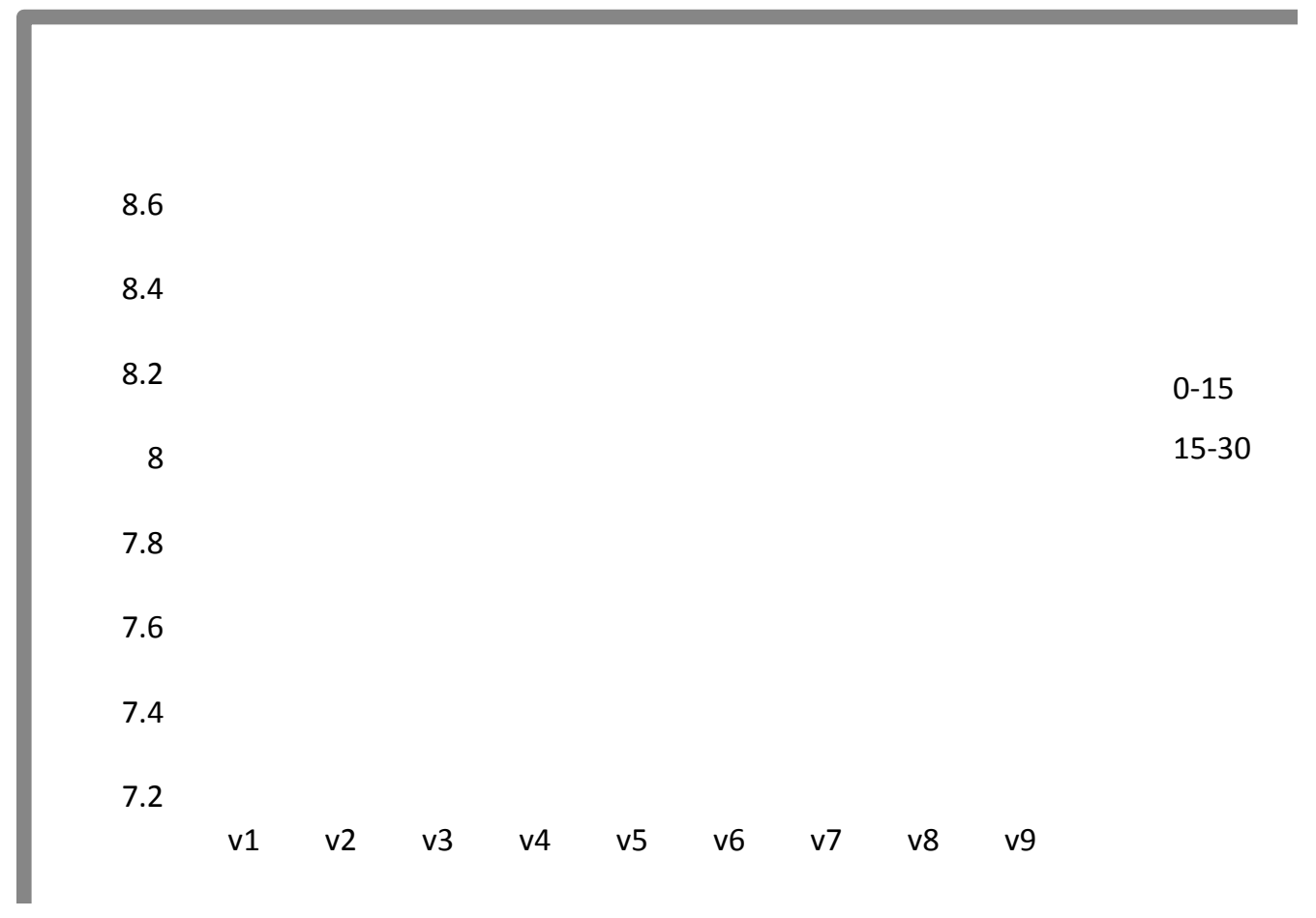


Fig.4 EC (dS m$\left.{ }^{-1}\right)$ of farmer's field at 0-15 and 15-30 cm depths

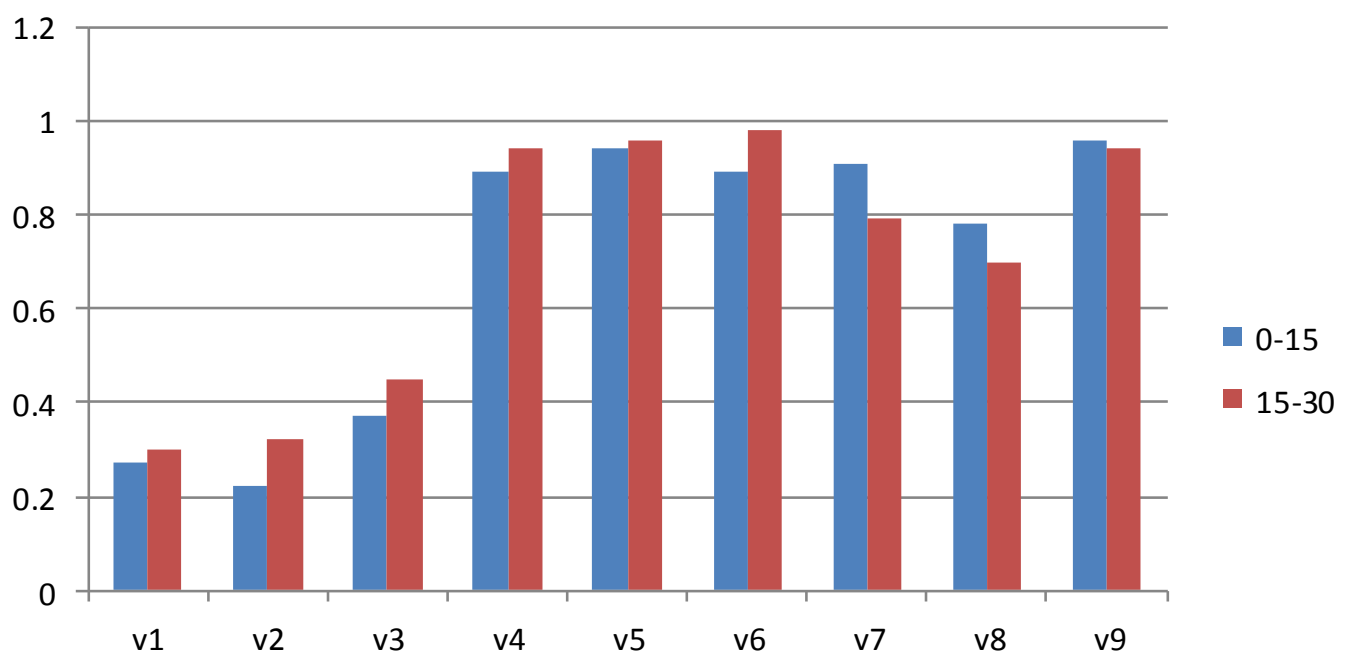

Fig.5 Available Nitrogen $\left(\mathrm{kg} \mathrm{ha}^{-1}\right)$ of farmer's field at 0-15 and 15-30 $\mathrm{cm}$ depths

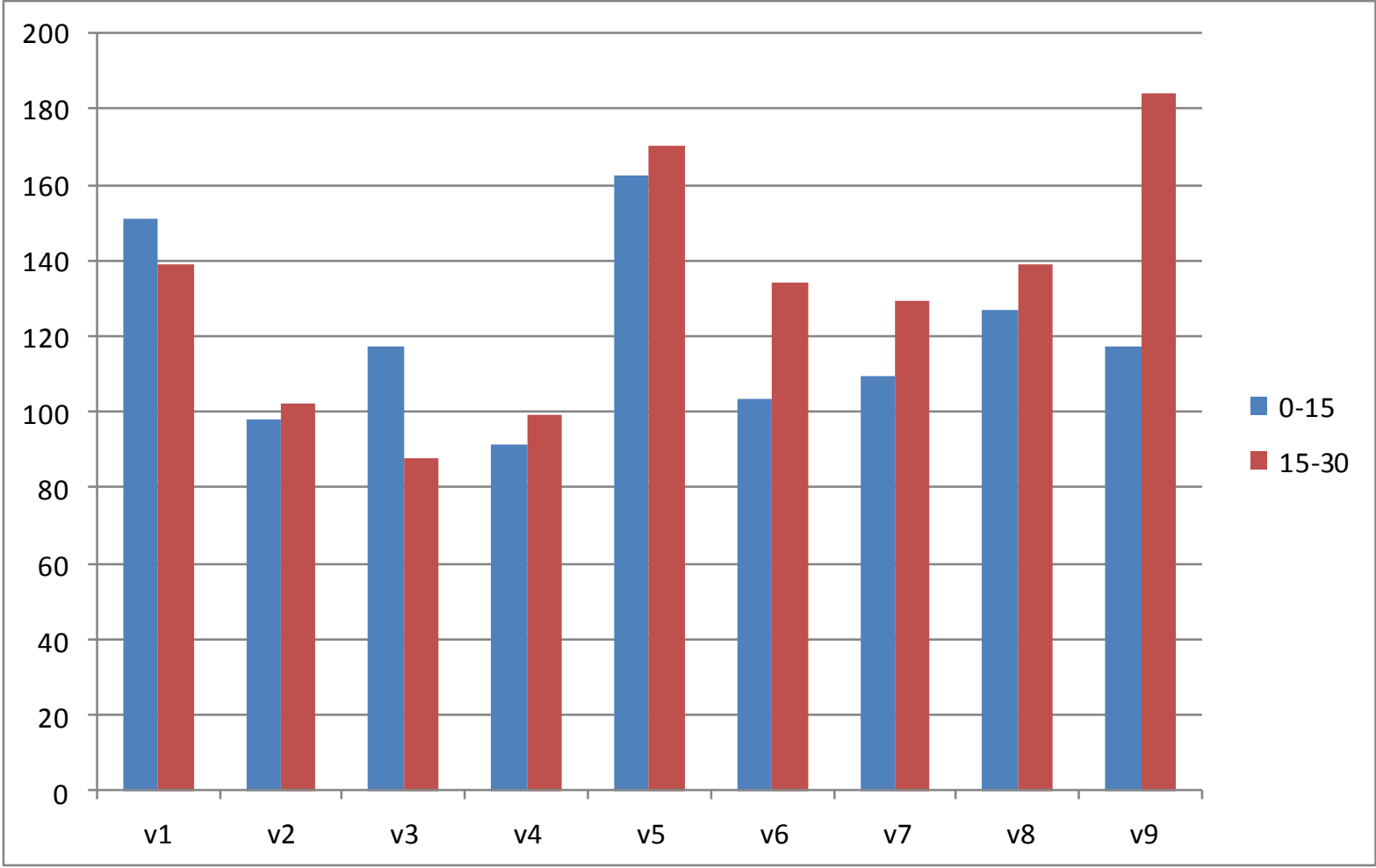


Fig.6 Available phosphorus $\left(\mathrm{kg} \mathrm{ha}^{-1}\right)$ of farmer's field at 0-15 and $15-30 \mathrm{~cm}$ depths

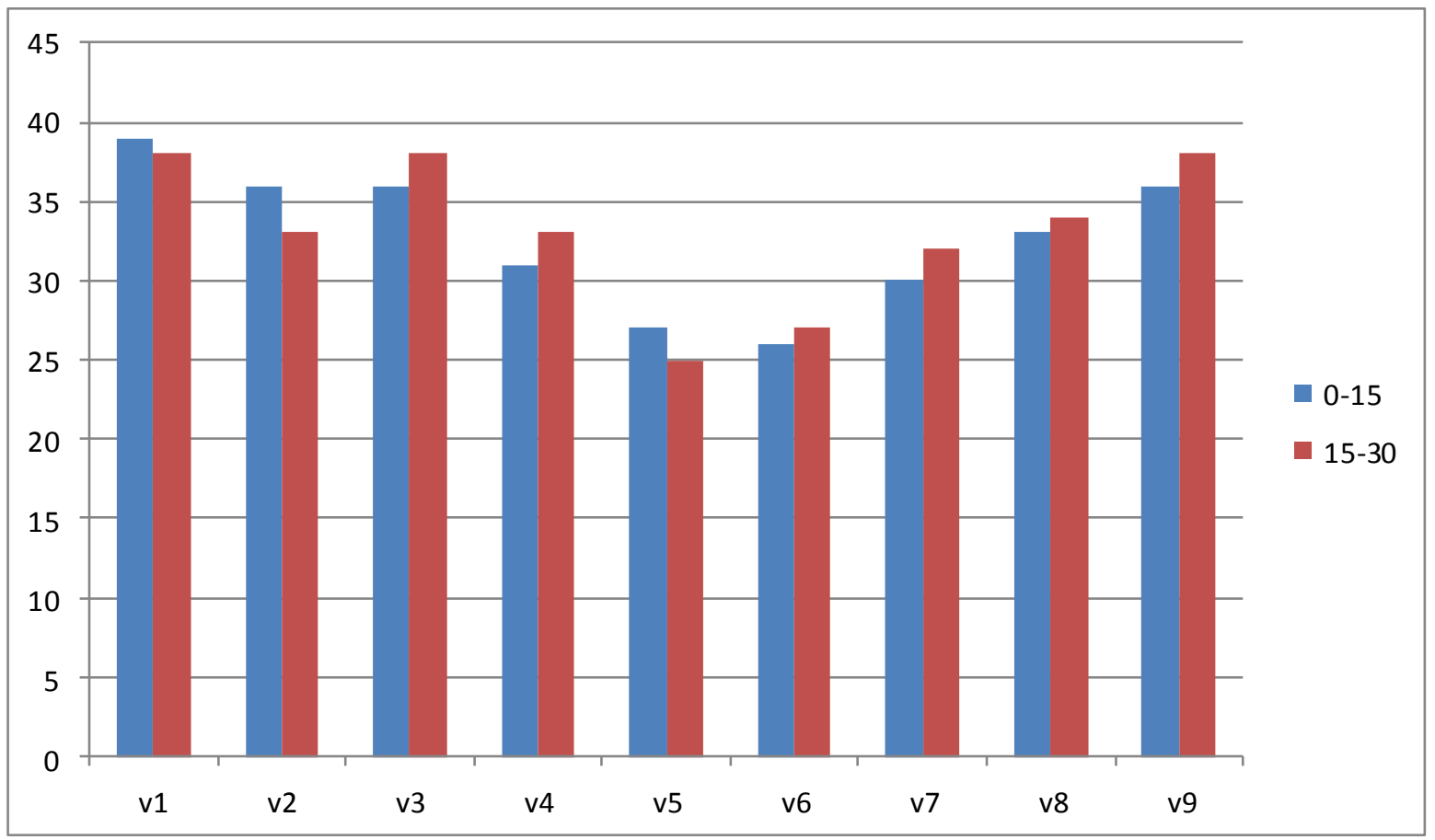

Fig.7 Available potassium $\left(\mathrm{kg} \mathrm{ha}^{-1}\right)$ of farmer's field at 0-15 and 15-30 cm depths

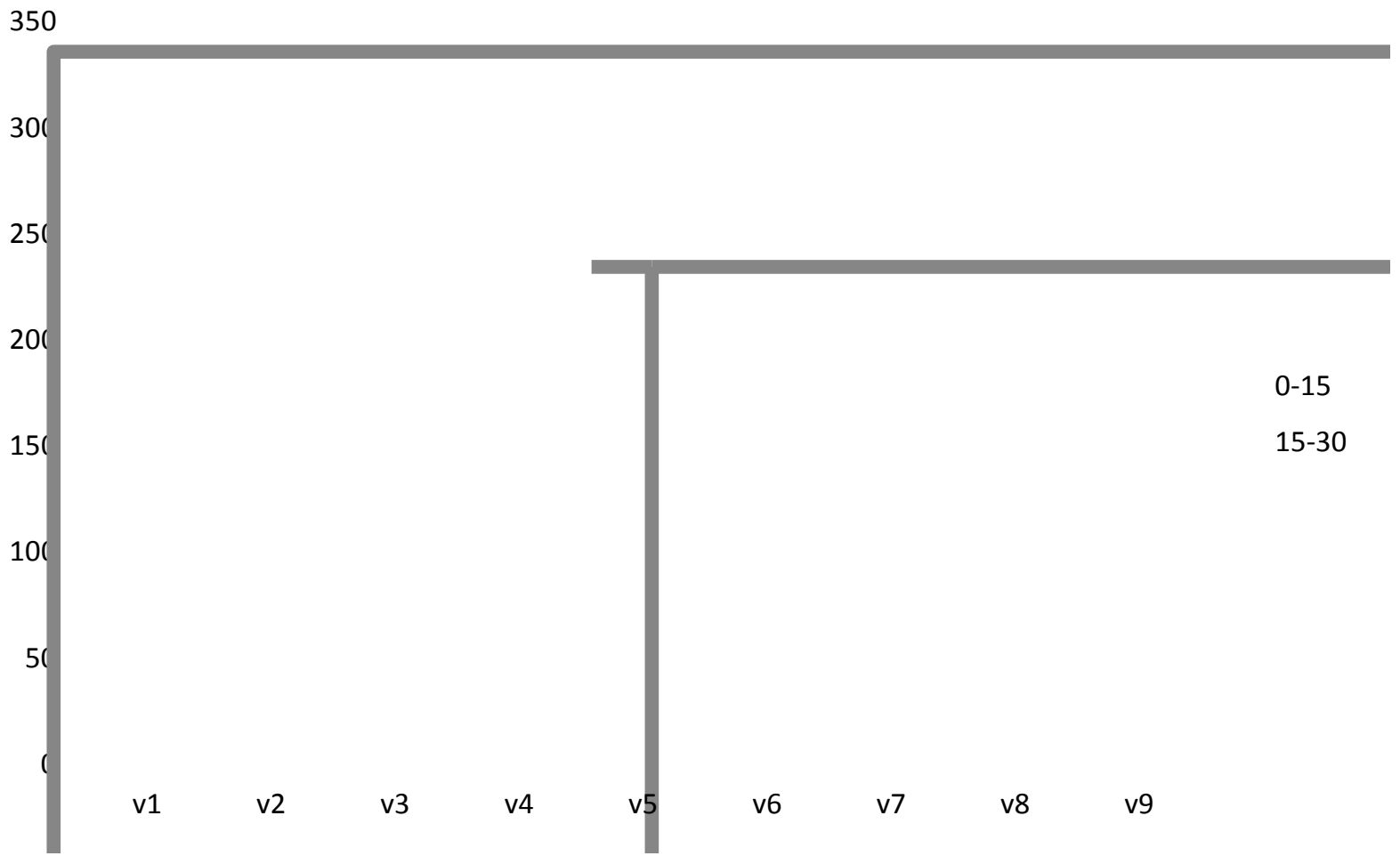


The Table.1 and Figure.4 depicted the statistical accumulation on EC of various farmers field and depths. The highest mean value is recorded $0.95 \mathrm{dS} \mathrm{m}^{-1}$ and the least mean value $0.27 \mathrm{dS} \mathrm{m^{-1 }}$.EC of this region soils $0-15 \mathrm{~cm}$ depth is various in between 0.22 $-0.96 \mathrm{dS} \mathrm{m}-$.At the depth of $15-30 \mathrm{~cm}$ of soils showing $0.30-0.98$ dS $\mathrm{m}-1$. Comparatively $0-15 \mathrm{~cm}$ depth is showing fewer amounts EC than $15-30 \mathrm{~cm}$ depth.. The Table 1 and Figure 1.5 depicted the statistical accumulation on Nitrogen $\left(\mathrm{kg} \mathrm{ha}^{-1}\right)$ of various farmers field and depths which was found to be non significant. The $\mathrm{N}$ ranges from 98.3 $162.75 \mathrm{~kg} \mathrm{ha}^{-1}$ at $0-15 \mathrm{~cm}$ and $87.5-184.1 \mathrm{~kg}$ $\mathrm{ha}^{-1}$ at $15-30 \mathrm{~cm}$. The highest mean value is recorded is $166.47 \mathrm{~kg} \mathrm{ha}^{-1}$ and the least mean value $95.3 \mathrm{~kg} \mathrm{ha}^{-1}$.The Table 1 and Figure 1.6 depicted the statistical accumulation on available phosphorus $\left(\mathrm{kg} \mathrm{ha}^{-1}\right)$ of various farmers field and depths. The $\mathrm{P}$ ranges from $26-36 \mathrm{~kg} \mathrm{ha}^{-1}$ at $0-15 \mathrm{~cm}$ and $25-38 \mathrm{~kg} \mathrm{ha}^{-1}$ at $15-30 \mathrm{~cm}$ depth. The highest mean value is recorded 38.5 and the least mean value $26 \mathrm{~kg}$ $\mathrm{ha}^{-1}$.

The Table.1 and Figure.7 depicted the statistical accumulation on potassium $\left(\mathrm{kg} \mathrm{ha}^{-}\right.$ ${ }^{1}$ ) of various farmers field and depths. The $\mathrm{K}$ ranges from $169-298 \mathrm{~kg} \mathrm{ha}^{-1}$ at $0-15 \mathrm{~cm}$ and $173-283 \mathrm{~kg} \mathrm{ha}^{-1}$ at $15-30 \mathrm{~cm}$ The highest mean value is recorded $290.5 \mathrm{~kg} \mathrm{ha}^{-1}$ and the least mean value $171 \mathrm{~kg} \mathrm{ha}^{-1}$.

\section{References}

Adikua, S. G. K. , G. Osei a , T. A. Adjadeh a \& G. N. Dowuona (2007) Simplifying the Analysis of Soil Particle Sizes. I. Testof the Sur and Kukal's Modified Hydrometer Method Communications in Soil Science and Plant Analysis, 35:13-14, 1995-2003

ArshiIram and TI Khan (2018)Analysis of Soil Quality Using Physico-Chemical Parameters with Special Emphasis on
Fluoride from Selected Sites of Sawai Madhopur Tehsil, Rajasthan. Int J Environ Sci Nat Res 12(5) (125-132

Gurjar, O.P., RamawatarMeena and Achinkumar and Surya Kant (2017)

Soil Fertility Status of Mandal Block in Bhilwara District of Rajasthan,India. International Journal of Current Microbiology and Applied Sciences ISSN: 2319-7706 Volume 6 Number 9 1154-1158

Hukam Singh Kothyari, K. C. Meena, B. L. Meena and RamkishanMeena (2018)Soil Fertility Statusin SawaiMadhopur District of Rajasthan Int. J. Pure App. Biosci. 6 (4): 587-591

Mahesh Kumar, S.K. Singh1 and B.K. Sharma (2009) Characterization, Classification and Evaluation of Soils of Churu District, Rajasthan Journal of the Indian Society of Soil Science, Vol. 57, No. 3, pp 253-261

Pravin R. Chaudhari, Dodha V. Ahire, Vidya D. Ahire, Manab Chkravarty and Saroj Maity Soil Bulk Density as related to Soil Texture, Organic Matter Content and available total Nutrients International Journal of Scientific and Research Publications, Volume 3, Issue 2, 2250-3153

Rakesh Gothwal, Govind Kumar Gupta. (2018). Physico-Chemical Analysis of Soil during Summer Season in Lentic Fresh Water Ecosystem: Nakki LakeMount Abu WSN 115 (2019) 117-127

Ramana1, Y.V. Singh, L. K. Jat, Santosh K. Meena Lakhapati Singh, H.S. Jatav and AlpanaPaul. (2015). Available Macro Nutrient Status and their Relationship with Soil PhysicoChemical Properties of Sri Ganganagar. Journal of Pure and Applied Microbiology, Vol. 9(4), p. 2887-2894

Sanjay Kumarbhati. (2017). Chemical Analysis of soil fertility parameters in 
Sri ganganagar and Hanumangarh District of Rajasthan. IJIRMPS 5 (4).

Singh, Y.V., Shashi Kant, S.K. Singh, P.K. Sharma, L.K. Jat, M. Kumar, S.K. Shahi, H.S. Jatav and R.N. Yadav. 2017. Assessment of PhysicoChemical Characteristics of the Soil of Lahar Block in Bhind District of Madhya Pradesh (India). Int.J.Curr.Microbiol.App.Sci. $\quad$ 6(2). 511-519.

Subbaiah, B.V. and Asija, G.K (1956) A rapid procedure for utilization of available nitrogen in Soil.Curr.Sci.26: 258-260.

Tan (1945) Observed the procedure of soil sampling.

Toth and Prince, (1949) Estimation of available potassium.

VarshaPandey, PoonamGautam and AP Singh
(2018) Assessment of physical properties of soil under different land use systems in a Mollisol Journal of Pharmacognosy and Phytochemistry ; 7(6): 2645-2648

Vikram Kumar1*, Jahangeer2, PadmNabh Tripathi3 and Shaktibala Comparative study of soil physical characteristics of Jaipur district, Rajasthan (2017) African Journal of Environmental Science and Technology Vol. 11(1), pp. $45-55$

Walkley, A. and Black, I.A (1934) Estimation of Degtjareft method for determinining soil organic matter, and a proposed modification of chromic acid titration method. Soil Science 37,29-38

\section{How to cite this article:}

Priyanka Yadav, Narendra Swaroop and Tarence Thomas. 2020. Analysis of Physico Chemical Properties and Available Macro Nutrient Status of Soil Blocks of Alwar District Rajasthan, India. Int.J.Curr.Microbiol.App.Sci. 9(07): 1834-1842.

doi: https://doi.org/10.20546/ijcmas.2020.907.211 